\title{
Influence of Intrinsic and Extrinsic Learning Motivation in College Students on Choice of Majors at State Universities
}

\author{
Daud Effendi ${ }^{1)}$, Erna Multahada ${ }^{2)}$ \\ ${ }^{1)}$ Universitas Islam Negeri Jakarta, Indonesia \\ ${ }^{2}$ Universitas Mercu Buana Jakarta, Indonesia \\ E-mail: daud.effendi@yahoo.com,ernamultahada.em@gmail.com
}

\begin{abstract}
This study aims to discover the influence of intrinsic and extrinsic learning motivation in college students on choices of majors at state universities. Participants consisted of 556 students (in their first and third semesters, with an age range of 18-21 years) in the Faculty of Da'wa Science and Communication Science at a state university. Data on intrinsic and extrinsic motivation obtained through nonrandom sampling utilized a scale adapted from Harter, while choice of majors data employed a Likert scale derived from theory of determination. Multiple linear regression analysis was used to determine the effects of intrinsic and extrinsic motivation on students' choice of majors. Our results showed that extrinsic and intrinsic learning motivation have significant influence on choice of majors at state universities. Intrinsic and extrinsic learning motivation in college students contributed approximately $10.5 \%$ toward choice of majors, with a high significance level $(\mathrm{p}=0.000)$. Intrinsic learning motivation had greater influence on choice of majors, with a beta value of 106.9, whereas extrinsic learning motivation had a beta value of 85 .
\end{abstract}

Key Words: extrinsic motivation, intrinsic motivation, students, choice of majors

\begin{abstract}
Abstrak: Penelitian ini bertujuan untuk menemukan pengaruh motivasi belajar intrinsik dan ekstrinsik mahasiswa pada mata kuliah pilihan jurusan di perguruan tinggi negeri. Peserta terdiri dari 556 mahasiswa (di semester pertama dan ketiga, dengan rentang usia 18-21 tahun) di Fakultas Ilmu Dakwah dan Ilmu Komunikasi di sebuah universitas negeri. Data motivasi intrinsik dan ekstrinsik yang diperoleh melalui pengambilan sampel non acak menggunakan skala yang disesuaikan dengan Harter, sedangkan data pilihan jurusan menggunakan skala Likert yang berasal dari teori determinasi. Analisis regresi linier berganda digunakan untuk mengetahui pengaruh motivasi intrinsik dan ekstrinsik terhadap pilihan jurusan mahasiswa. Hasil penelitian ini menunjukkan bahwa motivasi belajar ekstrinsik dan intrinsik berpengaruh signifikan terhadap pilihan jurusan di perguruan tinggi negeri. Motivasi belajar intrinsik dan ekstrinsik pada mahasiswa memberikan kontribusi sekitar 10,5\% terhadap pilihan jurusan, dengan tingkat signifikansi yang tinggi $(\mathrm{p}=0.000)$. Motivasi belajar intrinsik memiliki pengaruh yang lebih besar terhadap pilihan jurusan, dengan nilai beta 106,9, sedangkan motivasi belajar ekstrinsik memiliki nilai beta 85 .
\end{abstract}

Kata kunci: motivasi ekstrinsik, motivasi intrinsik, siswa, pilihan jurusan

Influence of Intrinsic and Extrinsic Learning Motivation in College Students on Choice of Majors at State Universities. College students typically choose their majors at state universities only once. Since it is not easy to switch majors, if the original choice was not the correct one, it is a consequence that the student must accept. If the student cannot accept the mistake, he/she must return to the beginning to retest, although graduation is not guaranteed in this case. For students at state universities facing this choice, they must endure sometimes-undesirable learning conditions. Choosing a major must be resolved in adolescence as part of the search for identity (DePasque \& Tricomi, 2015).

Student motivation plays an important role in determining quality of education. Students usually choose a major that will prepare them for success in a profession with significant job gains (Hamdan-Mansour, Hamaideh, Azzeghaiby, Hanouneh, \& Aboshai- 
qah, 2015). Motivation to choose a major springs from several factors (1) economic factors, different income levels, expectations or views relating to conditions of employment, tradeoff between returns and risks of failure, (2) demographic factors: gender, SES (socioeconomic status), minority status who may be able to strengthen the traditional, and (3) a mixture of demographic and economic factors (for example, differences in expected incomes of graduates of various races and genders) (Harter, 1980). Another factor is encouragement or coercion from parents (Harter, 1981).

Satisfaction and a sense of belonging and engagement correlated to internal motivation and encouraged students to consider intrinsic motivation in making decisions about choosing majors (Harter, 1980). Intrinsic motivation is an important factor in learning, allowing students to gain educational knowledge by thinking while studying (Hamdan-Mansour, Hamaideh, Azzeghaiby, Hanouneh, \& Aboshaiqah, 2015) and improve academic achievement (Lepper, Corpus, \& Iyengar, 2005). Intrinsic motivation has been proven to be positively correlated with academic results (and the opposite with extrinsic motivation) (Poturak, 2014).Options for majors and the effects of intrinsic motivation and extrinsic motivation in learning on the choice of majors at state universities were under consideration in this study.

Choice of majors is a goal (motivation) decided students. Categories of motivation consisted of no motivation, external motivation, and internal motivation in determination of major. Students with no motivation (i.e., students not selecting their majors themselves because they feel there is no conformity and low competence) in major choice are irrelevant and have no intention in choosing their majors. External motivation relates to the selection of majors due to (1) external rules, meaning the determination of majors relies on rewards and punishments from outside the student or his/her own fulfillment; (2) introjection, meaning the determination of majors has no ego involvement and focuses on the approval of others; (3) identification, meaning assessing the activities and objectives of that support; or (4) integration, associated with the determination of subject selection as the result of hierarchical synthesis, such as with objectives and suitability. Internal motivation is, on the other hand, the determination of majors sourced from within the students, namely because they are interested in or enjoy and are satisfied with the choice.

\section{METHOD}

This study was designed to determine the effects of extrinsic motivation and intrinsic motivation on the choices of majors by students at state universities.

Intrinsic motivation. Intrinsic motivation is motivation to engage in an activity that comes from inside students. Extrinsic motivation. Extrinsic motivation is motivation to engage in an activity to achieve a goal that comes from outside the individual self and his/her urges.

The participants consisted of students in one faculty within all courses offered, represented as $n=566$ students, and were obtained by non-random sampling. Table 1 offers a general overview of the research subjects, consisting of first- and third-semester students at one state university in Indonesia.

\section{Table 1. Overview of Research Subjects}

\begin{tabular}{ll}
\hline & \# of Students \\
\hline Semester 1 & 305 \\
Semester 3 & 251 \\
Total Participants & 556 \\
\hline
\end{tabular}

Students in their first and third semesters from various departments were chosen as research subjects, totaling 556 people in the age range of 18-21 years, with 305 students in their 1st semesters and 251 students in their 3 rd semesters. Table 2 displays the distribution of students by department.

Table 2. Overview of Research Subjects by Major

\begin{tabular}{ll}
\hline Majors & \# of Students \\
\hline KPI (Islamic Broadcasting Communication) & 151 \\
KESSOS (Social Welfare) & 100 \\
MD Management (Da'wah) + MHU (Management of Hajj and Umrah) & $79+27$ \\
BPI (Guidance Counseling Islam) & 85 \\
PMI (Islamic Community Development) & 34 \\
Journalism & 80 \\
\hline Total Participants & 556 \\
\hline
\end{tabular}


Choice of majors based on theory of determination was modified into a Likert scale. Extrinsic and intrinsic motivation were measured based on a scale adapted from Harter's theory. Multiple regression analysis to test the hypothesis of the study utilized SPSS 21.

\section{RESULTS}

Results are shown in Table 3, demonstrating frequency and percentages of motivations on choices of major programs.

Table 3. Categories of Motivation in Decision-making about Major Program

\begin{tabular}{lll}
\hline Category & Frequency & Percentage (\%) \\
\hline No Motivation & 178 & $32 \%$ \\
Extrinsic Motivation & 245 & $44 \%$ \\
Intrinsic Motivation & 133 & $24 \%$ \\
\hline Total & 556 & $100 \%$ \\
\hline
\end{tabular}

Table 3 illustrates the three categories of motivation in choices of majors (1) there was no motivation in choice of majors in 189 students (32\%), (2) students with extrinsic motivation in the choice of majors totaled 234 (44\%), and (3) students with intrinsic motivation in the choice of majors totaled 133 (24\%). A more detailed classification, based on selection of majors within the faculty at the university, is shown in Table 4.

Table 4 illustrates that, for the 151 students in the Islamic Broadcasting Communication (KPI) major, more ultimately determine their choice of majors based on external motivation $(\mathrm{M}=34.52, \mathrm{~S}=3.763)$, followed by lack of motivation in choice of majors $(\mathrm{M}=$ 25.44, $\mathrm{SD}=3.273$ ), and then internal motivation underlying choice of majors $(\mathrm{M}=18.40, \mathrm{SD}=2.397)$.

For the 100 students in the Social Welfare major (KESSOS), external motivation affected choice of majors most $(\mathrm{M}=32.16, \mathrm{SD}=4.254)$, followed by lack of motivation $(\mathrm{M}=23.36, \mathrm{SD}=3.451)$, and then internal motivation $(\mathrm{M}=16.74, \mathrm{SD}=3.116)$.

For the 79 students in the Da'wah Management (MD) major, more students were externally motivated in choice of majors $(\mathrm{M}=34.2405, \mathrm{SD}=5.06930)$, followed by internal motivation $(\mathrm{M}=18.6076, \mathrm{SD}=$ 3.18417), and then no motivation in choice of majors $(\mathrm{M}=24.75, \mathrm{SD}=3.69500)$.

In the Management concentrations, Hajj and Umrah (MHU) (same specializations, with MD), undertaken by 27 students, more students were motivated externally in choice of majors $(\mathrm{M}=31.48, \mathrm{SD}=3.251)$, followed by no motivation $(\mathrm{M}=25.33, \mathrm{SD}=3.076)$, and finally, internal motivation $(\mathrm{M}=22.19, \mathrm{SD}=$ 2.558).

For the 85 students in the Islamic Guidance and Counseling (BPI) major, students' choices of majors were based on external motivation $(\mathrm{M}=33.49, \mathrm{SD}=$ $3.933)$, followed by no motivation $(\mathrm{M}=24.59, \mathrm{SD}=$ $3.339)$, and then internal motivation $(\mathrm{M}=17.75, \mathrm{SD}=$ $3.188)$.

In the Islamic Society Development (PMI) major, chosen by 34 students, the results showed that external motivation had the biggest impact on choice of majors $(\mathrm{M}=31.76, \mathrm{SD}=5.003)$, followed by no motivation $(\mathrm{M}=22.68, \mathrm{SD}=4.021)$, and then internal motivation $(\mathrm{M}=19.91, \mathrm{SD}=3.576)$.

Finally, for the 80 students in the Journalism department, more were motivated externally in choice of majors $(\mathrm{M}=29.73, \mathrm{SD}=3.987)$, followed by students with no motivation in choice of majors $(\mathrm{M}=$ $23.45, \mathrm{SD}=3.714)$, and then internal motivation in choice of majors $(\mathrm{M}=19.91, \mathrm{SD}=3.576)$.

Table 5 offers descriptive analysis of data dissemination, based on the intrinsic and extrinsic motivation of students in learning.

Motivation of students' learning was extrinsic in as many as 267 students ( $48 \%$ ), while motivation was intrinsic in as many as 289 students (52\%). Table 6 provides detailed data on extrinsic and intrinsic motiva-

Table 4. Student Research Data by Category of Motivation and Majors

\begin{tabular}{llllllll}
\hline $\begin{array}{l}\text { Program/ } \\
\text { Concentration }\end{array}$ & $\mathbf{N}$ & \multicolumn{2}{c}{ No motivation } & \multicolumn{2}{c}{ External motivation } & \multicolumn{2}{c}{ Internal motivation } \\
\cline { 3 - 8 } & & Mean & SD & Mean & SD & Mean & SD \\
\hline KPI & 151 & 25.44 & 3.273 & 34.52 & 3.763 & 18.40 & 2.397 \\
KESSOS & 100 & 23.36 & 3.451 & 32.16 & 4.254 & 16.74 & 3.116 \\
MD & 79 & 24.75 & 3.69500 & 34.2405 & 5.06930 & 18.6076 & 3.18417 \\
MHU & 27 & 25.33 & 3.076 & 31.48 & 3.251 & 22.19 & 2.558 \\
BPI & 85 & 24.59 & 3.339 & 33.49 & 3.933 & 17.75 & 3.188 \\
PMI & 34 & 22.68 & 4.021 & 31.76 & 5.003 & 16.65 & 3.773 \\
Journalism & 80 & 23.45 & 3.714 & 29.73 & 3.987 & 19.91 & 3.576 \\
\hline Total & 556 & 100 & & 100 & & 100 & \\
\hline
\end{tabular}


Table 5. Categories of Motivation of Students' Learning

\begin{tabular}{lll}
\hline Category & Frequency & Percentage (\%) \\
\hline Extrinsic Motivation in Learning & 267 & $48 \%$ \\
Intrinsic Motivation in Learning & 289 & $52 \%$ \\
\hline Total & 556 & $100 \%$ \\
\hline
\end{tabular}

Table 6. Overview of Student Learning Motivation by Subject

\begin{tabular}{lllllll}
\hline Descriptive Statistics & \multicolumn{7}{l}{ Extrinsic } & \multicolumn{3}{c}{ Intrinsic } \\
\cline { 3 - 7 } & \multirow{2}{*}{ N } & & Mean & SD & Mean & SD \\
\hline Motivation of Student Learning in MD & 79 & 21.29 & 2.403 & 21.90 & 2.262 \\
Motivation of Student Learning in Social Welfare & 100 & 19.57 & 1.991 & 21.27 & 2.269 \\
Motivation of Student Learning in KPI & 151 & 19.68 & 1.940 & 21.15 & 2.102 \\
Motivation of Student Learning in BPI & 85 & 19.42 & 1.636 & 21.41 & 1.960 \\
Motivation of Student Learning in PMI & 34 & 19.21 & 1.789 & 20.62 & 2.257 \\
Motivation of Student Learning in Journalism & 80 & 20.24 & 1.970 & 21.14 & 1.979 \\
Motivation of Student Learning in MHU & 27 & 18.52 & 1.868 & 20.44 & 2.651 \\
\hline Total & 556 & & & & \\
\hline
\end{tabular}

Table 7. Coefficient of Determination

\begin{tabular}{|c|c|c|c|c|c|c|c|c|c|}
\hline \multicolumn{10}{|c|}{ Model Summary ${ }^{b}$} \\
\hline \multirow[t]{2}{*}{ Model } & \multirow[t]{2}{*}{$\mathrm{R}$} & \multirow{2}{*}{$\begin{array}{l}\text { R- } \\
\text { Squared }\end{array}$} & \multirow{2}{*}{$\begin{array}{l}\text { Adjusted R- } \\
\text { Squared }\end{array}$} & \multirow{2}{*}{$\begin{array}{l}\text { Std. Error } \\
\text { of } \\
\text { Estimate }\end{array}$} & \multicolumn{5}{|c|}{ Change Statistics } \\
\hline & & & & & $\begin{array}{l}\text { R-Squared } \\
\text { Change }\end{array}$ & $\begin{array}{l}\text { F } \\
\text { Change }\end{array}$ & $\begin{array}{l}\mathrm{df} \\
1\end{array}$ & $\mathrm{df} 2$ & $\begin{array}{l}\text { Sig. F } \\
\text { Change }\end{array}$ \\
\hline 1 & $.324^{\mathrm{a}}$ & .105 & 102 & 9.636 & .105 & 32.525 & 2 & 553 & .000 \\
\hline
\end{tabular}

Table 8. Partial Regression Coefficients

\begin{tabular}{|c|c|c|c|c|c|c|}
\hline \multicolumn{7}{|c|}{ Coefficients $^{\mathrm{a}}$} \\
\hline & & \multirow{2}{*}{\multicolumn{2}{|c|}{$\begin{array}{l}\text { Unstandardized } \\
\text { Coefficients }\end{array}$}} & \multirow{2}{*}{\multicolumn{2}{|c|}{$\begin{array}{l}\text { Standardized } \\
\text { Coefficients }\end{array}$}} & \multirow[b]{3}{*}{ Sig. } \\
\hline & & & & & & \\
\hline \multicolumn{2}{|c|}{ Model } & $\bar{B}$ & Std. Error & Beta & $\mathrm{t}$ & \\
\hline \multirow[t]{3}{*}{$\overline{1}$} & (Constant) & 36.011 & 4.943 & & 7.286 & .000 \\
\hline & Intrinsic Motivation & 1.069 & .196 & .229 & 5.443 & .000 \\
\hline & Extrinsic Motivation & .850 & .205 & .174 & 4.142 & .000 \\
\hline
\end{tabular}

tion of the students when studying at state universities (according to majors).

In Table 6, data descriptions in the extrinsic motivation column were highest for students studying in the $\mathrm{MD}$ department $(\mathrm{M}=21.29, \mathrm{SD}=2.403)$, followed by students studying in the Journalism department (M $=20.24, \mathrm{SD}=1.970)$, with the rest balanced among those studying in the $\operatorname{KPI}(\mathrm{M}=19.68, \mathrm{~S}=1.940)$, Social Welfare $(\mathrm{M}=19.57, \mathrm{SD}=1.991)$, and PMI $(\mathrm{M}=$ 19.21, $\mathrm{SD}=1.789)$ departments and the concentration in MHU (part of the MD specialization, with $\mathrm{M}=$ $18.52, \mathrm{SD}=1.868)$.

In the intrinsic motivation column in Table 6, numbers were highest in students majoring in $\mathrm{MD}(\mathrm{M}$ $=21.90, \mathrm{SD}=2.262)$, followed by the BPI $(\mathrm{M}=21.41$, $\mathrm{SD}=1.960), \mathrm{KPI}(\mathrm{M}=21.15, \mathrm{SD}=2.102)$, Journal$\operatorname{ism}(\mathrm{M}=21.14, \mathrm{SD}=1.979), \mathrm{PMI}(\mathrm{M}=20.62, \mathrm{SD}=$
2.257) departments and, finally, the MHU concentration $(\mathrm{M}=20.44, \mathrm{SD}=2.651)$.

The magnitude of the coefficient of determination can be seen in the adjusted R-squared, as shown in Table 7. Based on the results in Table 7, the value of $\mathrm{R} 2$ was 0.105 , meaning that the percentages of influence of extrinsic and intrinsic motivation on students' learning combined has an effective contribution of $10.5 \%$, while the remaining $89.5 \%$ was influenced by other variables.

To determine the magnitude of each effect on students in the study, Table 8 demonstrates choice of majors. Intrinsic motivation contributed to selection of majors with a beta value of 106.9 and a significance level of $p=0.000$, whereas extrinsic motivation contributed to choice of majors with a beta value of 85 , with a significance level of $\mathrm{p}=0.000$. 


\section{DISCUSSION}

Our results demonstrated that influence of intrinsic and extrinsic motivation on choice of majors at state universities was very significant $(p=0.000)$. The effective contribution of intrinsic motivation and extrinsic motivation on students in the study was $10.5 \%$.

Based on our research data, the majority of students enter public universities motivated in major choice by external factors $(234$, or $44 \%)$, followed by lack of motivation in choice of majors $(189$, or $32 \%$ ), and then internally motivated in choice of majors $(133$, or $24 \%)$. Therefore, choices of majors in public universities are clearly dominated by external factors.

Analysis descriptions for the variable of choice of majors can be described as follows: based on our study of 151 college students with the KPI major, students select this major most frequently based on external motivation, followed by no motivation, and then internal motivation. The selection of the Social Welfare major, based on our study of 100 students, was most frequently based on external motivation, followed by no motivation, with internal motivation being the least. The selection of the MD major, based on our study of 79 students, was most frequently based on external motivation, followed by internal motivation, with no motivation being the least. MHU majors (27 students) were most frequently motivated externally in choice of majors, followed by no motivation, and then internal motivation. The selection of the BPI major, based on our study of 85 students, was most frequently based on external motivation, followed by no motivation, with internal motivation being the least. The selection of the PMI major, based on our study of 34 students, was most frequently based on external motivation, followed by no motivation, with internal motivation being the least. Journalism majors ( 80 students) were most frequently motivated externally in choice of majors, followed by no motivation, and then internal motivation.

Options for undergraduate majors are crucial because the impact of choice of majors is correlated with stable employment, career opportunities, salary, and job satisfaction. According to theory of determination, the fact that external motivation affected choice of majors more relates to factors of punishment and fulfillment and can spring from support for the intended purpose and autonomy (Harter, 1980). Although choices of student majors in public universities were found to be dominated by external motivation, motivation to learn in public universities was linked more frequently to intrinsic motivation than extrinsic motivation, judging by the beta value of the contribution of intrinsic motivation on students' choice of majors at 106.9, with a significance of $\mathrm{p}=0.000$. On the other hand, extrinsic motivation to learn in this selection of majors was 85 , with a significance of $p=0.000$. Descriptions of the research subjects show that students who had intrinsic motivation in learning were $289(52 \%)$, while students who were motivated to learn extrinsically were 267 (48\%). Study of students' learning motivation in each department found students were motivated more intrinsically rather than extrinsically.

\section{CONCLUSION}

At public universities, influence from extrinsic motivation and intrinsic motivation on students' choice of majors certainly exists. In fact, the effect is very significant. Our research found that the influence of intrinsic motivation on choice of majors in students in the study was greater than extrinsic motivation, while choices of majors were motivated externally. The effective contribution of extrinsic and intrinsic motivation was only $10.5 \%$, so the remaining $89.5 \%$ was influenced by other variables not examined in this study.

\section{REFERENCES}

DePasque, S. \& Tricomi, E. (2015). Effects of intrinsic motivation on feedback processing during learning. NeuroImage, 119, 175-186. doi:10.1016/j.neuro image.2015.06.046.

Hamdan-Mansour, A.M., Hamaideh, S. H., Azzeghaiby, S. N., Hanouneh, S. I., \& Aboshaiqah, A.E. 2015. Psychosocial correlates of motivation for academic accomplishment among university students. Open Journal of Medical Psychology, 4(1), 1-8. doi:10.4236/ojmp.2015.41001.

Harter, S. (1980). Scale of Intrinsic versus Extrinsic Orientation in the Classroom. PsycTESTS. Dataset. doi:10. 1037/t06098-000.

Harter, S. 1981. A new self-report scale of intrinsic versus extrinsic orientation in the classroom: Motivational and informational components. Developmental Psychology, 17(3), 300-312. doi:10.1037//00121649.17.3.300.

Jurusan Kuliah: Tips Memilih Jurusan Kuliah. (n.d.). Retrieved from http://belajarpsikologi.com/tipsmemilih-jurusan-kuliah. 
Lepper, M.R., Corpus, J.H., \& Iyengar, S.S. (2005). Intrinsic and extrinsic motivational orientations in the classroom: Age differences and academic correlates. Journal of Educational Psychology, 97( 2), 184 196. doi:10.1037/0022-0663.97.2.184.

Poturak, M. (2014). Private universities' service quality and students' satisfaction. Global Business and Economics Research Journal, 3(2), 33-49.
Santrock, J.W. (2008). A topical approach to lifespan development (8th ed.). New York: McGraw-Hill.

Soria, K.M. \& Stebleton, M. (2013). Major decisions: Motivations for selecting a major, satisfaction, and belonging. NACADA Journal, 33,(2), 29-43. doi:10. 12930/nacada-13-018. 